Revista Aspas

ppgac - USP

Entrevista

\title{
ENTREVISTA COM DULCE MUNIZ - MEMÓRIAS DE 1968
}

Entrevista realizada em 18 de outubro de 2018 no Teatro Studio Heleny Guariba, por Matheus Cosmo e Roberta Carbone. 


\section{REVISTA ASPAS - Pensando na sua história e no hoje, o que fica de 1968} para você? $\mathrm{O}$ que você acha interessante dizer sobre este momento?

DULCE MUNIZ - Acho que fica a esperança, o sonho, a coragem, a integridade, a doação, o companheirismo, a solidariedade! Eu não posso esquecer a Heleny Guariba, uma mulher de trinta anos, com dois filhos pequenos, que foi barbaramente assassinada e até hoje não sabemos aonde foi parar o corpo dela. Temos que pensar, por exemplo, no próprio capitão Carlos Lamarca, que era o filho dileto do exército brasileiro e largou tudo. Ele foi lutar no Canal de Suez e lá deu um troço na cabeça, que ele voltou com outras ideias. E ele também pagou com a própria vida! Não posso esquecer, por exemplo, o Bacuri, que teve a vida tirada aos poucos, arrancaram a sua orelha, furaram um olho... Não posso esquecer os estudantes todos, como o Edson Luís, que virou um símbolo, em março de 1968 no Rio de Janeiro. O José Guimarães, outro estudante assassinado pela ditadura em outubro de 1968 em São Paulo. Eu fui à casinha do Zé Guimarães, que ainda existe e hoje é uma pizzaria. Nós todos fomos ao enterro do Zé Guimarães e tivemos que ir até o IML, porque eles queriam nos roubar o corpo dele. Eu estava fazendo o cursinho do Grêmio da Filosofia na época. Em 1968 ainda era estudante, mas também já estava no teatro. E depois, em 1969, prestei o vestibular. Na Batalha da Maria Antônia, que foi em outubro de 1968 , os prédios ainda estavam sendo construídos, não eram todos que já existiam. E tinha gente lá em cima que era do CCC, Comando de Caça aos Comunistas, e do MAC, o Movimento Anti-Comunista, que jogava bomba e atirava! Tem um notório facínora, um delegado chamado Raul Careca - que, ao que parece, já morreu -, que tinha se formado pelo Mackenzie e era do CCC. O Mackenzie, nessa época, era um representante máximo da direita. Mas fica também o agradecimento por aquele momento, por aqueles dias tão duros de violência, mas em que as pessoas ainda pensavam em música. $\mathrm{O}$ Lênin não gostava de música. Ele falava que não podia compreender como, em um mundo como esse, as pessoas ainda tinham tempo para isso! Mas ele não gostava pelo lado bom. Então você vê quanta gente participou disso: Chico Buarque, Caetano Veloso, Gilberto Gil, Milton Nascimento, é tanta gente que nem dá para lembrar todos. Tem também as cantoras, a Elis Regina, por exemplo, que já começa em 1965. Em 1968, antes do Al-5, você tem uma explosão artística. O golpe de 1964 interrompe uma experiência inédita no Brasil de 
progressismo e de fazer valer direitos, mas ao mesmo tempo ele dá, e não tira das pessoas, a vontade de fazer coisas. Daí as peças, como a Primeira Feira Paulista de Opinião, Roda viva, peça contundente do Chico Buarque que o Zé Celso se encarregou de tornar ainda mais contundente, tanto que foi invadida pelo CCC. No teatro, por exemplo, tem o Augusto Boal, o Zé Celso Martinez Corrêa, a Cacilda Becker e os grupos de teatro, como o Opinião, com o João das Neves. Tem os escritores maravilhosos, por exemplo o Carlos Heitor Cony, que escrevia no Correio da Manhã, um jornal que foi golpista! Mas toda a imprensa foi golpista! O jornal Última Hora parece que foi o único não golpista, mas eu não me lembro muito bem e preciso consultar os livros para saber com certeza. Mas quando foi no quarto ou quinto dia da ditadura, todos já estavam escrevendo contra. Tinha o Otto Maria Carpeaux, que era uma sumidade, e aparece também a História Nova, feita pelo pessoal do Nelson Werneck Sodré, o Joel Rufino Santos, que era um jovem historiador e se tornou um grande escritor que foi preso por muito tempo. $\mathrm{E}$ as mulheres, como a lara lavelberg, que é um símbolo. Ela tenta vencer todos os limites que tem e morre querendo fazer tratamento para ter filho! Quando eu escrevi a peça sobre ela em 2000, lara, camarada e amante, ainda falavam que ela tinha se matado. Ela não se matou! Eu tenho absoluta convicção disso. Eu li tudo que saiu, tudo que tem dela eu li. Uma mulher que estava tentando engravidar não ia se dar um tiro de jeito nenhum. Ela ia tentar passar por debaixo da porta, virar ectoplasma, menos se matar. Como também a Heleny. $E$ tem as pessoas que ainda estão vivas, como a Amelinha Teles, a Crimeia de Almeida, que tem uma prole pequena, porém combativa: a Janaína, o Edson e o Jó. E agora a Crimeia tem também uma neta, a Aurora. Essas mulheres sofreram, mas sofreram demais! E elas são frequentemente atacadas. Querem humilhar, desmenti-las e falar que elas são mentirosas. E a Amelinha está hoje falando na televisão! Essa mulher também é de 1968. Então, eu sou da seguinte opinião: - aliás, eu tenho falado essa frase em todo lugar - o começo pode ter sido ruim, mas nós podemos tentar melhorar o final. Nem sei de quem é essa frase, mas a repito. Eu, que tinha dezesseis anos quando veio o golpe de 1964, depois passei por 1968, pelas Diretas Já, e passo agora por esse golpe de novo... Porque isso é um golpe! Se você comparar, por exemplo, com o que aconteceu com o Paulo Maluf, durante quantos anos ele ficou esperando para ser julgado? O Luiz Inácio Lula da Silva está 
sendo mantido preso por aquela porcaria daquela cobertura de quinta categoria, que depois o Guilherme Boulos se encarregou de mostrar que aquilo era porcaria mesmo. Eu dizia "O que é aquilo? Por causa de um puxadinho, uma porcaria de um sítio de que nem se tem provas!" O professor Fernando Henrique, quando ainda estava no governo, pôde reunir-se com toda a sua equipe para formar seu instituto. E, no entanto, o presidente Lula está preso! E a presidente Dilma foi tirada para quê? Para pôr este inominável, este ilegítimo no seu lugar. Faz dois anos que este homem tomou o poder e eles se encarregaram de acabar com tudo! E foi para isso mesmo que a Dilma foi golpeada. O que ela fez? Em vez de pagar a conta de luz daquele mês, ela pagou o telefone. Ela tirou de um lugar para cobrir outro, coisa que todo trabalhador faz. Nós fazemos isso aqui no teatro. Então 1968 eu penso que é exemplo também, é memória, é saudade. Eu lembro o Flávio Império quando ele fez a peça Os fuzis da senhora Carrar, do Bertolt Brecht, com aquele maravilho André Gouveia, que morreu já. Aquelas jovens atrizes, a Maria Esther Stockler, o José Agrippino Paula, que fez a peça Rito do amor selvagem, que tinha um globo de plástico central. As músicas, as letras, o Luiz Melodia, que vem depois; o Fauzi Arap, que era ator, se torna diretor e faz os shows da Maria Betânia; a própria Betânia, que aparece ainda menina, com dezessete anos, para substituir a Nara Leão; enfim, é disso que eu me nutro, do amor, da poesia. O Drummond, que já vinha de lá não sei onde; a Ana Cristina Cesar, que vem depois; a Cecília Meireles. A poesia que apareceu em 1968, o Márcio Felix, o Afonso Romano Sant’Anna, o Thiago de Mello, que fala "Faz escuro, mas eu canto porque amanhã vai chegar", o Geir Campos, que fala "Operário do canto, me apresento / Se há mais quem cante cantaremos juntos / Sem se tornar com isso menos pura / A voz sobe uma oitava na mistura / Para enganar o tempo - ou distrair / criaturas já de si tão mal atentas, / não canto... / Canto apenas quando dança, / nos olhos dos que me ouvem, a esperança." Quer dizer, é disso que se trata! Para mim, de 1968 eu me lembrarei sempre. Eu me lembro das torturas, das mortes, dos assassinatos, das violências contra os trabalhadores, do meu pai e da minha mãe, que tinham que sair de São Joaquim da Barra para visitar meu irmão, um trabalhador que estava preso aqui em São Paulo. Mas também me lembro do Dom João Angélico Sândalo Bernardino, que na época ainda era padre e foi rezar nossa missa de formatura; do arcebispo de Ribeirão Preto que, em 1969, 
excomungou os delegados torturadores de lá; da Madre Maurina, que foi presa e torturada. Eu vou sempre me lembrar disso, mas eu tenho que me lembrar das coisas boas também. Eu não consigo enumerar o bem que a esquerda, que agora está sendo vilipendiada, fez. As melhores coisas foram feitas pela esquerda. Os sonhos que nos foram transmitidos e estimulados foram pela esquerda. Eu tive um professor de português maravilhoso, que não era de esquerda, era até um conservador, mas que adorava poesia, literatura, teatro e nos ensinou a gostar. A minha professora de canto orfeônico que seguia as cartilhas do Villa-Lobos e nos ensinava a reger, a solfejar, nos ensinou o parabéns brasileiro, do Villa-Lobos e do Manuel Bandeira: "Saudamos o dia / Em que comemoras / Seja a casa onde mora / A morada da alegria / O refúgio da ventura / Feliz aniversário." E nós, no entanto, ficamos no Parabéns pra você, e tem alguns que até falam happy birthday. Eu tive um professor de História que foi a primeira pessoa que me falou alguma coisa semelhante a direitos humanos, que ainda não era isso. Uma turminha gente boa naquele período. E tudo vem então formar esse 1968 que, a despeito de ter transformado o Brasil em uma noite escura, eu ainda me lembro das coisas boas. Apesar de tudo, os brasileiros daquele tempo, os trabalhadores se comprometeram com a luta pela vida, assumiram essa luta.

ASPAS - Houve o golpe de 1964 e depois o golpe dentro do golpe em 1968, com o Al-5, mas isso não impediu uma grande explosão, principalmente, no campo da arte. E você diz que um golpe se dá agora de outro modo neste contexto atual. Você acha que também hoje houve uma explosão artística ou que, de algum modo, a arte conseguiu lidar com esse golpe? DULCE - Não, agora acho que não. Em 1968, tudo foi amordaçado e já tinha sido em 1964. Os sindicatos estavam praticamente fechados. Em 1970, vem a formação da guerrilha, dos grupos de contestação e de luta contra a ditadura. Por exemplo, tem um operário, o Olavo Hansen, que foi preso e nem era guerrilheiro, ele era do Partido Operário Revolucionário Trotskista, o PORT, e foi assassinado na tortura. Depois, têm as lutas democráticas, as jornadas democráticas que começam em 1976, 1977 e a luta pela anistia, que vai desembocar na criação do Partido dos Trabalhadores. O PT é, pela primeira vez na história do Brasil, um partido formado por operários. O Partido Comunista 


\section{não era formado por operários e o pessoal do PT até brincava que ele} era o único partido que tinha cúpula operária e base intelectual. $E$ nós vamos caminhando, com altos e baixos, até chegar em 2014. Os problemas, para mim, já começam em 2013. Eu não fui naquela onda, eu não tenho o mito da juventude comigo. Uma primeira coisa me chamou a atenção naquelas pessoas em 2013. Desde 1967, o ícone, o grande homem da liberdade, que tinha sido assassinado pelo Capital, pelo imperialismo norte-americano, era Guevara. E, a partir de 1967, nenhuma manifestação que se dizia a favor da população, a favor dos trabalhadores, a favor de direitos, a favor das conquistas das mulheres deixou de estampar a fotografia de Ernesto Guevara. Mas em 2013 não tinha, eu olhei! Eu apelidei aqueles meninos de block bostas porque para mim era isso. Eu não posso tirar trabalhador de dentro do ônibus para colocar fogo! Eu não posso ameaçar trabalhador! Mas eles faziam isso. lam para os pontos de ônibus onde havia trabalhadores indo para o trabalho, os tiravam dos ônibus e incendiavam. Aquilo já me pareceu a direita se transfigurando, como se fosse uma lagarta. Aqui na frente do teatro, nós pusemos uma fotografia da Dilma, uma fotografia do Lula e uma fotografia do Guevara. Mas finalmente o capitalismo acabou matando o Guevara. Porque, se você fala do Guevara, agora, acho que te executam na hora. Em 2013, tem a eleição e aquele cafajeste daquele neto começa tudo isso quando pede a recontagem de votos e põe em dúvida a lisura das urnas. Ali começa tudo. Para mim, os meninos do Passe Livre foram engolidos. E isso vai resultar nesta coisa horrível da FIESP [Federação das Indústrias do Estado de São Paulo]. Este senhor que foi candidato agora com aquela carinha de mocinho bonitinho - também não falo o nome dele -, daquele partido que falam que é Novo, foi um financiador dos grandes. Quem tinha dinheiro? A Fiesp colocava os meninos da direita para tomar café lá dentro. Não era assim? A Fiesp não abria [para a esquerda]. Tanto que nós ficávamos no Masp e, eles, na Fiesp. Depois eles também nos roubaram o Masp. Eles vão roubando! A classe dominante é terrível, ela não tem vergonha na cara. Ela foi se apropriando das coisas, a ponto de o filho deste coiso estar em cima de um caminhão de som com um revólver! Todo mundo viu, não sou eu que estou falando. E junta com essa indecência do PSDB. Por isso acho que a ação, a atitude do professor Fernando Henrique é muito grave neste momento. Ele não pode confundir o 
fascismo com a esquerda, que pode ter feito e que está pagando. O Lula está até preso sem provas. Ele não pode comparar o fascismo com o PT, dizendo que o partido fez isso, fez aquilo. Vamos deixar para depois esta grande lavação, mas agora um perigo maior chega a nós. Aí tem o golpe realmente, o golpe judicial, que não precisa mais da mão do militar. E vem este senhor que todo mundo "adora", aquele juiz que parece o Torquemada de Curitiba, e dá um golpe! Olha o que ele fez agora com aquela denúncia do Palocci. O Palocci falou aquilo em abril! Todo mundo sabia o que ele falou, não tinha nada que ele ainda não tivesse dito, e esse juiz mandou publicar a mesma denúncia, desprezando e manipulando a população. Mas eu penso que as artes não tiveram caldo suficiente para coisas muito boas acontecerem. Por exemplo, quem apareceu como dramaturgo em 1968? O Plínio Marcos com Jornada de um imbecil até o entendimento. O Plínio já tinha aparecido antes, mas ele fica mais forte em 1968. Eu acho que tanto na música quanto no teatro não teve igual ao que foi 1968. Aqui em São Paulo, por exemplo, tem o teatro de grupo - não sei se no Rio tem tanto, dizem que não. Esses grupos tentam fazer teatro sobre escombros, tentam falar sobre as necessidades e sobre a história que nós estamos vivendo. E nós não falamos do Vandré, que também já vinha de antes. O Vandré faz uma música que o exclui de tudo. Eu acho que hoje tem gente que tenta, tem autores, tem gente que tenta fazer música legal. Eu acho que apareceu, por exemplo, este menino de quem eu gosto muito, o Marcelo Jeneci. Tem outro que acho que vocês nem conhecem, o Rubi, que era de um grupo de teatro daqui. Tem também o Filipe Catto. Entre as meninas, a Mallu Magalhães apareceu antes desse negócio, ela tinha quinze anos e se fortaleceu. Tem a Ana Cañas, as meninas negras que apareceram como cantoras maravilhosas. Tem o Johnny Hooker, que eu adoro. Eu gosto dessa coisa escandalosa, que era muito da música brasileira. O meu pai era operário e ouvia rádio, só rádio. Não tinha televisão. E eu fui formada por aquilo tudo e pelo rádio. O rádio tinha coisas muito boas; tinha a Rádio Nacional do Rio de Janeiro, que fazia o programa da UNE; tinha, por exemplo, a Nora Ney, que era comunista, a Dircinha Batista, Linda Batista, Isaurinha, Dalva de Oliveira! A Dalva então, com aquela briga com o Herivelto, cantava: "Risque meu nome do seu caderno!" Tinha outra maravilhosa que eu acho que não morreu ainda, chama-se Lana Bittencourt, que também cantava 
rock. E o Johnny Hooker, para mim, é um pouco essa coisa. Eu gosto desses meninos que fazem essas músicas românticas porque eu fui formada assim, eu escutava isso. Tinha o Tito Madi, que acabou de morrer, a Maísa: "Se você me encontrar pelas ruas," "Ouça, vá viver / Sua vida..." Eu acho que tem um pouco disso ainda, a despeito da nossa herança, a despeito do massacre dos índios, da violação dos negros, dos direitos massacrados, da independência ter sido proclamada pelo filho do rei, da República ter sido proclamada por um marechal com as braguilhas abertas que dizem que estava bêbado - não sei se é verdade. E agora ainda temos um novo historiador, o presidente do Supremo, que acaba de dizer que o golpe não é mais golpe e sim movimento!

ASPAS - E pensando nos movimentos feminista e LGBT, que ganham força em 1968, como eles chegam a esta conjuntura atual?

DULCE - Primeiro, não é exatamente em 1968 que isso começou, porque ali nós ainda vivíamos sob a égide de alguns outros costumes. Mesmo nos grupos chamados progressistas, era muito difícil, por exemplo, aceitarem homossexuais e mulheres nas próprias organizações. Quando o Partido dos Trabalhadores é fundado, demora não sei quantos anos para que se tenha uma primeira presidente. A primeira mulher presidente do Brasil não teve coragem de ir sozinha no desfile em carro aberto do dia da posse e precisou que a filha dela fosse junto. Quer dizer, se confunde o particular, o privado e o público. Isso é oriundo de 1968. Mas, em 1968, nós tínhamos uma mulher maravilhosa chamada lara lavelberg que, de certa forma, confrontava com sua presença, com sua vida e seus hábitos. Ela namorava todo mundo, fazia as coisas, era absolutamente emancipada. Acho que a lara já nasceu emancipada, apesar de ser judia e de trazer nas costas uma história de sofrimento. Claro que houve outras mulheres nessa época, mas a verdade é que essas não eram bandeiras de jeito nenhum. Tanto que o Herbert Daniel, que era um dos dirigentes da Vanguarda Popular Revolucionária, a VPR, sofria muito por ser homossexual. E há notícias também que, no próprio Partido Comunista, os homossexuais não podiam nem entrar. Claro que eu nunca achei que a esquerda fosse um bloco monolítico, apesar da hegemonia do Partido Comunista em certo momento. E é por isso que nós diferenciamos a esquerda da direita. A direita é monolítica, mesmo quando ela parece ser diferente. Eu tinha dezesseis anos 
em 1964 e lembro que uma mulher de trinta anos estava conversando com a minha mãe, mas parecia que elas tinham setenta, oitenta anos. Hoje eu tenho setenta anos e vocês que são jovens falam: "Não, mas você está jovem!" Eu faço questão da minha velhice, eu reivindico a velhice, mas quero dizer que era difícil naquela época, muito difícil. E, agora, neste período, querem esquecer que nós tivemos outro tempo em que lutas puderam ao menos existir e ser reconhecidas por uma grande parcela da população. Dizem que, em cada dez famílias, pelo menos três delas têm um homossexual e têm um negro porque, afinal, nós somos herdeiros de negros e índios. Eu gosto de falar que nós temos um conglomerado de siglas, agora temos mais duas, o "Q" e o "l." Porque, é claro, nós somos uma sociedade pluralista e diversa, muito diversa. E a nossa história é muito trágica, por isso nós temos esta imensidão de possibilidades que luta muito para conseguir poder andar de mãos dadas com seu namorado. Eu sempre pensei que a luta dos homossexuais avançaria mais as relações humanas do que a mera relação heterossexual. Não que não se possa ter casamento e que não se possa ter filhos, a humanidade afinal vive disso, mas o casamento não precisava ser essa coisa que virou uma reivindicação. Mas eu entendo, porque é muito difícil você não poder nem falar o que todo mundo fala. E, na minha modesta opinião, esse conglomerado de siglas sofre muito mais preconceito que, contra eles, é muito mais violento do que contra os negros, que sofrem um preconceito horrível. Não sei se é porque cada um de nós traz em si mesmo a dualidade ninguém é tão homem nem tão mulher, e não precisa ser -, mas eu percebo que as pessoas reagem muito mal à homossexualidade. Outro dia falaram assim para mim: "Ah, eu sou contra a homossexualidade", aí eu falei "Bobagem sua! Vai ser contra mais o quê? Contra a chuva? Vai ser contra o sol? Não existe isso, cara!" São manifestações que não dependem da nossa vontade. $\mathrm{E}$, se por acaso acontecer esta coisa inenarrável, inominável nestas eleições, essa comunidade vai sofrer mais que todas as outras porque nós somos um conjunto de fragilidades. As mulheres, apesar de terem conquistado muitas coisas, quantas são assassinadas! Anteontem foram três de uma vez! E isso é o que nós sabemos, mas e naqueles mocambos, naqueles lugares que nós não vemos?! Quantas filhas são estupradas pelos pais?! Esse cara não é um monstro, ele pensa de uma forma tão retrógrada, tão antiquada, pensa que 
ele é o provedor e que, portanto, quem tem que procriar com as filhas é ele também. Então, para mim, se avizinha muito sofrimento para os trabalhadores em geral, para as mulheres, para os negros e negras e, principalmente, para os homossexuais. O Congresso nunca teve tanto militar eleito, não precisa mais golpe militar. Nunca se elegeu tanta Bíblia e a bancada do boi, então, nem se fale. As pessoas falam que o Congresso será renovado, quem o renovará? Não há nenhum movimento de transformação ali. Mas nós ainda temos dez dias! Não são mais os Doze Trabalhos de Hércules, mas são dez. Eu pensei nos Doze Trabalhos de Hércules quando faltavam doze dias. Então eu penso que vai ter muito sofrimento. Todos estes meninos e meninas que se transformam visualmente vão sofrer tanto repúdio! Eles vão sofrer, inclusive, violências físicas, eu penso. Pabllo Vittar, Maria Gadú, Laerte, você pensa: a Laerte vai poder entrar em algum lugar? Eu estou falando desses, mas tem um monte de meninos e meninas que se apresentam como mulheres ou como homens. E, na minha modesta opinião, está tudo bem! O que você está fazendo, se não está prejudicando o outro, para mim está tudo bem! Mas, infelizmente, nós não fizemos, de fato, valer nossas conquistas nestes anos em que pudemos governar. $E$ isso eu acho triste. Os governos "populares" - e isso eu acho que foi um erro político - não fizeram parceria com quem deveriam ter feito, ficaram na mão do capital financeiro e se aliaram à direita. Imagine chamar o Joaquim Levy, que era dono de banco, para ser Ministro da Fazenda ou o Henrique Meirelles para ser presidente do Banco Central! Você chama a raposa para cuidar das uvas?! O que é isso?! E as demandas populares, as lutas populares foram indo, claro. Tem o MST, o Stédile, as mulheres... Se isso tivesse tido um movimento diferente, talvez hoje nós não estivéssemos nas condições em que estamos, em que um homem da dignidade, da integridade de um Fernando Haddad é comparado a um pústula, que eu não falo nem o nome.

\section{ASPAS - Você poderia falar um pouco sobre a sua trajetória no teatro neste momento? Contar sobre o seu contato com a Heleny Guariba e com o Augusto Boal?}

DULCE - Eu cheguei de São Joaquim da Barra a São Paulo no dia 27 de janeiro de 1968. Tinha aquelas passeatas, aquelas greves, a Maria Fernanda já 
tinha sido suspensa de Um bonde chamado desejo, do Tennessee Williams. A censura suspendeu a Maria Fernanda porque ela fez não sei o que. E aí eu conheci o Hélio Muniz, que foi meu primeiro marido, e comecei a fazer teatro com um grupo chamado Casarão porque nós alugamos um casarão antigo e o reconstruímos, tiramos as paredes. E eu participei de todas as passeatas, das reuniões que eu podia ir, que eu ficava sabendo. Aí fui morar com o Hélio em uma garagem que tinha ali na Rua Jandaia. O Hélio e eu moramos em uma garagem! Nós tínhamos uma espiriteira, compramos uma panela e uma lata que tinha quatro tipos de doces: pessegada, figada, goiabada e marmelada. Chegamos a participar de um festival com uma poesia do Brecht e com uma do Mário de Andrade. Nós estávamos ensaiando $O$ pagador de promessas, mas brigamos com ele e o largamos. Então nós alugamos outra casa, uma casinha que ainda existe ali na Rua Baronesa de São Joaquim, um quarto e sala que tinha banheiro. E, nesse lugar, teve uma coisa muito importante: eu escondi uma mulher que era casada com um senhor que tinha sido preso com o filho e o genro. Eles foram os responsáveis por aquela pintura com as cores do exército no caminhão que o Lamarca ia usar para tirar as armas do quartel. Mas, quando eles estavam pintando o caminhão, um menino chegou e perguntou o que eles estavam fazendo e alguém deu um peteleco no moleque, que saiu e falou para mãe que alguém tinha batido nele. A mãe chamou a polícia, que pegou todos eles! E a mulher foi ficar na minha casa porque tínhamos um amigo em comum. Aí veio um anúncio dizendo que o Teatro de Arena iria dar continuidade a seu curso de interpretação, cujos professores seriam Heleny Guariba, Cecília Thumim, o professor Baldur e Mercedes Baptista, bailarina maravilhosa da dança brasileira. Nós conhecíamos o nome da Heleny porque ela tinha dirigido George Dandin, do Molière, em 1968. A Cecília nós também conhecíamos porque ela tinha participado da Primeira Feira Paulista de Opinião e já estava casada com o Boal. E conhecíamos a Mercedes Baptista de nome. Naquela época, tinha pouco teatro em São Paulo, e todo mundo se conhecia. Às vezes, em uma reunião, tinha a Cacilda Becker e eu, que ninguém sabia quem era. Para fazer as assembleias, as reuniões, toda a classe teatral cabia dentro de um teatro. Aí nós começamos a fazer o curso do Arena. Nós militávamos, o Hélio trabalhava no banco e militava na oposição bancária, no PORT. Além de todos de que falei, depois o 
Rodrigo Santiago também nos deu umas aulas. Nós fizemos o curso e tínhamos que apresentar alguma coisa de encerramento. Tivemos que fazer $O$ casamento do Fígaro, do Beaumarchais, que a Heleny ia dirigir para o Arena ganhar o dinheiro da Comissão Estadual de Teatro para ir para o La MaMa, em Nova lorque, apresentar as peças que eles tinham: Arena conta Zumbi, Arena conta Bolívar. Essa peça que nós íamos fazer ia dar o dinheiro para o Arena viajar. Só que a Heleny, em 1969, já estava comprometida completamente com a luta armada e não conseguia fazer a peça. Ela queria que a Myrian Muniz e não sei mais quem fizesse os papéis dos mais velhos e nós, os jovens, fizéssemos os jovens. E ainda tinha o Música Antiga, que era um grupo musical que tocava música antiga, o Flávio Império fazendo os figurinos e cenários... Era muita coisa! Não sei como ia sobrar dinheiro para eles viajarem! Mas aí a Heleny sumiu e o Boal pegou a peça para dirigir. Nós finalmente começamos a fazer a peça e a Heleny aparecia de vez em quando. Eu me lembro, por exemplo, que ela foi nos dirigir em São Bernardo ou São Caetano, não me lembro, em uma das cidades em que nós tínhamos que apresentar para ganhar o dinheiro. Eu lembro que ela ficava sentada de olhos fechados enquanto nós fazíamos a peça e dizia: "Dulce! Esta sua voz não tem nada a ver com seu corpo quando eu abro o olho!" Bom, e nós fomos fazendo até que chegou a apresentação de São José dos Campos, não me esqueço disso também, porque ela falou que ela ia, mas não chegava. Quando ela chegou, nós já estávamos quase indo embora e fomos para cima dela: "Heleny, você não tem vergonha?! Fala que vem e não vem! O que é isso?!" Mal sabíamos que dali a pouco... Ainda tentamos fazer As troianas com o Antônio Pedro e não deu certo, mas também foi uma grande experiência. Aí acabou 1969, o pessoal do Arena ia para o La MaMa, nós não sabíamos onde a Heleny estava e, com esse pessoal que conhecemos em São José dos Campos, bolamos uma mostra de teatro amador, que foi feita aqui em São Paulo. Enquanto isso, o Boal já tinha falado para nós do Teatro Jornal. O Celso conta que foi em um jantar, mas isso não existiu, ele se confunde porque nós fazíamos jantares entre nós. E depois dessa mostra de teatro amador, nós decidimos desenvolver o Teatro Jornal de que o Boal sempre falava. Pegávamos o jornal, escolhíamos as matérias, era um jeito nosso de fazer. Éramos Denise Falótico, Celso Frateschi, Edson Santana, Hélio Muniz, Elísio Brandão e eu. O 
Marcos Weinstock fazia os cenários e os figurinos porque nós só tínhamos umas camisetinhas, aquela coisa do Areninha, e tinha também o Mário Masetti, meu adorado amigo que, infelizmente, vai fazer dois anos que morreu. Nós pegávamos as notícias, líamos e dramatizávamos. Nós fomos fazendo isso até que o Boal voltou e nós falamos “Nós fizemos, Boal!". E eu acho, não tenho certeza disso, pode ser que eu esteja inventando, que o Boal falou: "Bom, o que será que fizeram? Vamos ver!" E nós mostramos para ele. Aí ele começou a marcar sessões clandestinas em que vinham o Anatol Rosenfeld, o Giannotti, o Octavio lanni, o Jean-Claude Bernardet, essa gente que era da academia. E aí chegou um dia em que ele falou para nós: "Vamos pôr em cartaz." E nós “Mas como, Boal?”, e ele: “Vai..." Ele mandou o texto para a censura e chegou o dia do homem assistir à peça porque, além de mandar o texto para a censura, que já podia proibir e cortar lá, nós ainda tínhamos que fazer um espetáculo para a censura. Olha que capacidade esta classe mandona brasileira tem: ainda nos obriga a fazer coisas para o algoz! É uma coisa de maluco! Mas o Boal era um gênio e acho que ele foi um grande mestre. Em 1970, eu tinha vinte e dois anos, acho que o Celso tinha dezessete, a Denise, dezoito e o Hélio, vinte e três, que ele é um ano mais velho do que eu. Éramos crianças! Bom, aí o Boal falou para nós: "Olha aqui, isso não passa na censura de jeito nenhum, mas, agora, vocês vão provar que são de fato atores, vai ser o exame de vocês. Vocês têm que enganar o censor!" Veio o homem da censura e nós fizemos. Terminou a peça e o homem da censura falou o quê? "Meus filhos, me desculpem, mas vocês têm que melhorar. Vocês estão muito fraquinhos." Aí o homem desceu - nós fazíamos lá em cima - e o Boal falou "Vai ver se ele já saiu" porque, além de tudo, alguém tinha que descer para levá-lo. O homem já tinha ido embora e o Boal falou: "Parabéns. Vocês são atores." Era uma coisa da maior violência, era tudo o que acontecia e que nós dramatizávamos. Tanto é que, quando nós fomos para o Festival de Teatro de Nancy, as pessoas falaram: "Como?!" A Annina, que tinha ido embora porque era advogada de presos políticos e estava ameaçada, me agarrava pelo braço e dizia: "Dulce! Você não pode voltar para o Brasil! Depois desse espetáculo você não pode, você vai ser enquadrada na lei de segurança nacional, artigos 31, 45 - sei lá o que! Você vai ficar aqui comigo!". "Não, Annina! Olha aqui a nossa liberação." "Hã?!" "É, nós conseguimos fazer isso!" O Boal tinha sido 
preso e foi nos encontrar lá. Nós fizemos toda a temporada, as pessoas gostaram demais, falavam muito de nós, uns queriam que nós ficássemos. Nós tivemos assistência de maravilhosas pessoas. O Alberto Cavalcanti, o cineasta, foi nos assistir e ficou encantado com o Celso. O Caetano estava lá e foi nos assistir também. Ele ria na cena do seu Benedito, o homem com as bexigas, que dava facada na palavra-cruzada. O Roberto Schwarz, o Mário Soares, o Hélder Costa, o Sebastião Salgado, não vou lembrar os nomes de todos que estavam lá, só sei que essa gente ia nos assistir e falava "Nossa! Que coisa! Que espetáculo!” O Boal estava fora de contato e nós fizemos uma campanha no mundo inteiro e aqui no Brasil também. Aí ele chegou e nós falamos: "O Boal vai ficar, claro. E nós vamos voltar porque nós temos que lutar contra a ditadura!" Era junho ou julho, não me lembro muito bem, mas isso está escrito em algum lugar, nós chegamos aqui e pegamos o Arena porque o Boal não estava mais e a Cecília também não. Então resolvemos fazer Doce América, Latino América, que era em cima das histórias dos maias, dos incas e dos astecas e ainda colocamos uma cena do Brasil e uma da Argentina, escritas pelo Plínio Marcos. O Mário Masetti fez o som, o Marcos Weinstock fez os cenários e figurinos e aí veio o Antônio Pedro. Eles também tinham viajado conosco porque ao nosso Teatro Jornal se somou o Arena conta Zumbi. Quando nós voltamos para o Brasil, o Boal e a Cecília foram para a Argentina. E, claro, o Boal se tornou o homem do mundo, foi até indicado ao prêmio Nobel. Mas, desgraçadamente, ele foi muito torturado pelo Sérgio Fernando Paranhos Fleury quando foi preso. E, como as pessoas falam, atentado, tortura, tudo isso abrevia a vida. Certamente ele viveria muito mais porque ele era de uma têmpera, um homem de fazer as coisas que ele fazia. E nós ficamos então no Arena, fizemos o Doce América, Latino América com música do Théo de Barros e, como nós tínhamos ido para a Argentina, colocamos também músicas da Mercedes Sosa, que nunca ninguém tinha ouvido falar. Colocamos muitas outras coisas que nós fizemos na temporada do Teatro Jornal no Teatro del Centro. E a vida continuou, só que nós brigamos com o Luís Carlos Arutin. Eu e o Hélio morávamos em cima do Arena, que tinha um apartamentinho atrás. E, um dia, quando nós fomos colocar a chave, não entramos. Brigamos com o Arutin e eu não queria mais ficar lá. Contei isso para o querido Maurício Segall e, durante todo o período em que eu 
estava grávida e depois que minha filha nasceu, ele pagou o meu salário até o sexto mês. Ele foi meu grande amigo, meu protetor. Eu tinha adoração pelo Maurício! Ele nos acolheu e o Fernando Peixoto também foi conosco. O Fernando então dirigiu primeiro a peça Tambores na noite, do Brecht, depois Semana de arte moderna, do Carlos Queiroz Telles e Frei Caneca, do Telles, também. Aí eu briguei com ele antes do Frei Caneca e falei "Eu vou embora! Ou eu mato o Fernando ou o Fernando me mata." Mas depois eu voltei a ficar muito amiga dele. Ele veio várias vezes aqui nesse teatro, fez leitura aqui comigo, eu adorava o Fernando. Um ator extraordinário! Como diretor ele dava muito trabalho mesmo, mas eu gostava muito do Fernando e lastimo que ele tenha morrido. $\mathrm{E}$ ninguém me tira da cabeça que o Fernando morreu porque ele ficou no ostracismo. Ele foi um homem muito ativo, era diretor, autor, ator, ensaísta, trabalhava, escrevia, redigia e era um articulador! E aí você perde isso?! A solidão mata! Bom, eu fui embora e foi aí que o Maurício ficou me pagando até eu ter a minha filha. Depois, eles montaram um grupo que também se separou. O Celso, a Denise e outros montaram um núcleo de teatro na Penha e o Hélio foi para o Ipiranga e montou o TTT - Truques, Traquejo e Teatro. Eu fiquei na cidade e fui trabalhar com a Marilena Ansaldi e com a Ruth Rachou, que me convidavam às vezes para fazer uma peça. Trabalhei com o Antônio Abujamra no TBC [Teatro Brasileiro de Comédia] e fiz o projeto Cacilda Becker com ele. Depois montei com meu compadre, que também já morreu, o Antônio Maschio, peças para criança e produzimos algumas coisas da Marilena Ansaldi, uma mulher extraordinária, que fazia coisas lindíssimas. Em São Paulo, cada vez que ela estreava uma peça, a cidade ficava em polvorosa! Teve uma época em que eu trabalhei muito com o pessoal da dança. Aí fundei esta princesinha que chamava Duma e nós montamos $A$ bruxa colorida, do Manoel Carlos Karam, que também já morreu, com o Márcio Aurélio dirigindo. Depois nós montamos $A$ lenda do vale da lua, do João das Neves, que também morreu recentemente, com o Mário Masetti dirigindo. Foi um espetáculo maravilhoso! Acabamos também nos separamos, o Antônio Maschio abriu o Pirandello, que foi um sucesso durante anos. Daí eu conheci o Roberto Ascar, juntamos também com o Demas de Francisco... e agora eu pulei um pedação. Fiz o Bambalalão na TV Cultura para crianças durante não sei quantos anos, muito legal, eu adorei. Fiz alguma novela na TV 
Bandeirantes, fiz alguma participação na TV Globo, naquelas quartas móveis em que tinha o Caso Verdade. Aí viemos para cá em 1996. Eu estava ensaiando uma peça do Demas de Francisco, Caixa de retratos, e conheci a Ariela, que era dona daqui. Eles tinham reaberto o espaço com o nome de Teatro de Câmara de São Paulo, mas aqui já tinha sido a Sala Cineclube Oscarito e a Sala Sérgio Cardoso do Cine Bijou. No Teatro de Câmara de São Paulo era a Lavínia Pannunzio, o Jairo Mattos, o Luis Frugoli, o Bosco Brasil e a Ariela Goldmann. Ela estava aqui, mas ia entregar para o dono e nós assumimos o espaço em 1996. Nós o reinauguramos em fevereiro de 1997 com o nome de Teatro Studio 184. Fizemos um monte de coisa, sempre com essa vocação de receber coletivos, fazer debates, leituras, homenagens. Homenageamos muita gente. Nós ganhamos o Recreio nas Férias, depois ganhamos o nosso primeiro fomento ao teatro com o projeto Heleny 65-35, porque fazia trinta e cinco anos de seu desaparecimento e ela faria sessenta e cinco anos, se estivesse viva. Todos os nossos projetos têm mais ou menos a mesma estrutura: pessoas que vêm contar sua história, que é o Diário do Cidadão, sempre também tentando fazer uma peça para crianças, um pequeno debate e trazendo coisas da História mais recente, mais atual. Eu escrevi as peças Heleny, Heleny, doce colibri, lara, camarada e amante, Roda vermelha, que é sobre a grande Rosa Luxemburgo, Bacuri/Jonas Jonas/Bacuri, O interrogatório brasileiro, inspirada na peça do Peter Weiss. Eu faço peça para crianças, brigo na categoria. Em 1978, participei da fundação da CUT [Central Única dos Trabalhadores]. Em 1980, participei da fundação do Partido dos Trabalhadores com muita honra e orgulho. Fui muito próxima do Luiz Inácio Lula da Silva, que ainda nem era Luiz Inácio Lula, era só Luiz Inácio da Silva. Fizemos um show lindíssimo para eles, em que a Elis cantou pela primeira vez $O$ bêbado e a equilibrista. Fui presa em 1970, quando o Olavo Hansen foi assassinado. E isso foi um grande problema porque na época nós não podíamos falar e tínhamos medo de que pudesse acontecer alguma coisa com ele. Mas, depois, claro, todo mundo já falava que de fato o Olavo tinha sido assassinado. A própria Heleny desapareceu em 1971 e depois ficamos sabendo que ela também tinha sido assassinada na Casa da Morte, em Petrópolis. Agora, as dúvidas que ficam e ninguém nunca vai descobrir são se corpo foi esquartejado $e$ dissolvido no ácido, se foi jogado em alto-mar ou se foi enterrado em algum 
lugar da Rodovia Rio-Santos. A morte da Heleny e a do Olavo são mortes muito emblemáticas para mim. A Heleny era minha professora, eu fiquei muito amiga dela e ela gostava muito de mim. Eu tenho certeza que a minha vida, se a Heleny não tivesse morrido, seria outra. Mas, de qualquer forma, eu tento honrar essas pessoas. Eu tenho profunda admiração pelo Boal, pela Cecília, que fez o seminário sobre o Boal aqui, o Boal também veio aqui, o Izaías Almada, que foi do Arena antes de mim, participou do seminário sobre o Boal. A Cecília veio várias vezes aqui e eu fiz depoimentos para o Boal. De vez em quando topo com o Celso, com a Denise, que inclusive foi minha protetora e outro dia me emprestou dinheiro para pagar o aluguel. E eu vou vivendo. Agora estamos passando por este momento tão duro, esta noite escura que quer se abater sobre nós. Mas eu continuo acreditando, apesar da direita estar renascendo sem vergonha agora. Porque antes ela tinha vergonha, agora ela não tem, ela tem orgulho de ser de direita. Mas, apesar de tudo, eu continuo acreditando.

Edição de Roberta Carbone

Publicado em 06/05/2019 